\title{
Caring and Carers: Diplomatic Personnel and the Duty of Care
}

\author{
Halvard Leira \\ Norwegian Institute of International Affairs (NUPI), N-0033 Oslo, Norway \\ Halvard.Leira@nupi.no
}

Received: 1 March 2017: revised: 2 June 2017: accepted: 30 October 2017

\section{Summary}

This article deals with the duty of care that states hold in relation to their citizens abroad - more specifically, the double role of diplomatic personnel, as both providers and recipients of care. The focus of discussion is states' duty of care for diplomatic personnel, raising questions of how this care can be balanced with the duty of care for citizens and how far this duty stretches. The article first emphasizes the threats, before focusing on the means of protection: evacuation; physical structures; and psychological care. A tension remains, for as states fulfil their duty of care towards personnel through increasing security, they might at the same time reduce their personnel's capacity to provide care for citizens. One solution for this tension - outsourcing and local personnel — tests the limits of care.

\section{Keywords}

Duty of care - consular assistance - embassies - diplomatic personnel - threats protection - outsourcing

* This article was written within the project 'Duty of Care: Protecting Citizens Abroad', which was financed by the Research Council of Norway (grant number 238066/H2o). Earlier versions were presented at the 2015 International Studies Association (ISA) Annual Convention and at a workshop at the Clingendael Institute in June 2016, and the author thanks all who were present for their feedback. The author is also especially grateful to Nina Græger, Kristin M. Haugevik, and the peer reviewers and editors of The Hague Journal of Diplomacy for their detailed comments. 


\section{Introduction}

On 21 June 1870, the French consul to Tianjin in China, Henri-Victor Fontanier, playing the role of protector of French citizens and Catholics more generally, sought the help of Chinese officials to break up an angry anti-Christian mob. At some point, Fontanier shot and killed one of the local magistrate's assistants, whereupon the mob attacked and killed both Fontanier and his assistant. Subsequently, 30 to 40 Chinese converts were also killed, as well as 21 foreigners, in what has become known as the Tianjin massacre. ${ }^{1}$ While massacres are few and far between, and few consular and diplomatic agents suffer the fate of Fontanier, diplomatic personnel are still at risk while caring for their compatriots. Indeed, the risks seem to be multiplying, for both citizens abroad and diplomats. For states, these developments imply a number of challenges, concerning legitimacy, morality, law, politics and economics.

These challenges can fruitfully be approached under the heading of 'duty of care' that states hold for citizens abroad. ${ }^{2}$ Asserting such a duty necessarily also entails that someone must implement it - there must be carers involved. The states' diplomatic personnel ${ }^{3}$ thus have two different roles in the 'chain of care' connecting states and citizens abroad: ${ }^{4}$ they are intermediaries in the state's provision of care for its citizens abroad; but are also themselves recipients of care from the state. In the case of the unlucky Fontanier, both links in the chain broke: he was unable to provide care for his countrymen; and the French state was unable to provide care for him. States and carers face similar and additional dilemmas today. Care for citizens in new, sometimes riskprone places must be combined with care for carers, as diplomats and their infrastructure have become more frequent targets of violent attacks. The main focus in this article is on these providers of care, and two specific questions are raised. First, how is it possible for states to perform their duty of care towards

1 Xiaoli Tian, 'Rumor and Secret Space: Organ-Snatching Tales and Medical Missions in Nineteenth-Century China', Modern China, vol. 41, no. 2 (2015), p. 209.

2 Nina Græger and Halvard Leira, The State's Duty of Care in International Relations, paper presented at the ISA Convention, Atlanta, GA (2016).

3 Here, 'diplomatic personnel' includes all personnel related to the foreign services of states, but not other representatives of states or officials of international organizations; see J. Craig Barker, The Protection of Diplomatic Personnel (Aldershot: Ashgate, 2006), pp. 17-28.

4 The notion of a 'chain of care' is used here as a heuristic, illustrating how the duty of care extends from the state, through different care-providers, to citizens. See Arlie Russel Hochschild, 'Global Chains of Care', Review of Women's Studies, vol. 11, no. 1-2 (2001), pp. 197209; and Nicola Yeates, 'Global Care Chains: A State-of-the-Art Review and Future Directions in Care Transnationalization Research', Global Networks, vol. 12, no. 2 (2012), pp. 135-154. 
their citizens, while also upholding their duty of care towards their diplomats? Second, what are the limits to care for diplomatic personnel — that is, how far does the duty stretch?

The first research question is handled in the first two sections of the article. First, the role of diplomatic personnel as care providers is discussed. Second, the focus turns to diplomatic personnel as recipients of care. Here, threats against the carers are discussed, and three strategies of care are discussed, logically sorted from the acute to the permanent, ranging from immediate physical care in cases of evacuation, through the long-term physical care that is inherent in securing infrastructure and training of personnel, to the psychological care (or lack thereof) of diplomats who have been dispatched to hardship posts.

One specific response by states to the growing tension between protection of citizens and protection of diplomats has been delegation and outsourcing, both of diplomatic tasks and of security. This leads to the second question above: what are the limits to the duty of care for diplomatic personnel, and what sort of duty of care do states hold towards contractors and locally hired staff? This is discussed in the third section of the article, both in terms of the sometimes-blurred boundaries between diplomats and contractors, and in light of the acute boundary-drawing taking place in times of evacuation.

The existing literature on these topics is limited and scattered across disciplines as diverse as tourism studies, studies of crisis management and occupational medicine. Consular diplomacy has received increased attention in recent years, ${ }^{5}$ but the focus has been more on the consuls' activities as providers of care than on consuls and diplomats as recipients of care. The exception to this rule can be found in ongoing research dealing explicitly with the duty of care. ${ }^{6}$ Located within that research project, this article should be read as a heuristic study, raising an agenda rather than drawing definite conclusions. Accordingly, the conclusion will first draw some tentative deductions about state responses to the tension of care, before returning to the holes in the literature, suggesting where diplomatic studies could broaden its agenda.

5 Jan Melissen and Ana Mar Fernández (eds.), Consular Affairs and Diplomacy (Leiden: Brill, 2011).

6 See, for example, Jan Melissen and Matthew Caesar-Gordon, "Digital Diplomacy" and the Securing of Nationals in a Citizen-Centric World', Global Affairs (2016), Dor: 10.1080/23340460 .2016.1239381; and Maaike Okano-Heijmans and Matthew Caesar-Gordon, 'Protecting the Worker-Citizen Abroad: Duty of Care Beyond the State?', Global Affairs (2016), DoI: $10.1080 / 23340460.2016 .1245388$. 


\section{Care for Citizens}

Do polities care about their compatriots abroad? The short answer is yes, at least for states seeking legitimacy from their citizens and having the capacity to act when need be. This can be seen in both regulations and practice. Some states have a legal definition of care written into their foreign service laws, ${ }^{7}$ and developed and developing countries alike have in recent years evacuated citizens from countries in crisis. ${ }^{8}$ While care for compatriots is typically discussed as a recent phenomenon that is related to the increase in tourism and migration and the growing reach of the state, polities have a long track-record of caring for at least some activities of their compatriots abroad. Such care (or at least interest) is a relatively common historical phenomenon, pre-dating the emergence of modern states by millennia. However, the forms that this interest has taken have varied greatly, and the articulation of a duty of care is a much more recent phenomenon. The novelty of the phenomenon should not obscure the potential moral and political repercussions for embassies or ministries that fail to uphold this duty, towards citizens in general and diplomatic staff in particular. The aftermath of the Benghazi attack in 2012, which left the us ambassador to Libya, one other us Foreign Service official and two Central Intelligence Agency (CIA) contractors dead, should make the potential liabilities evident. This section will briefly outline the historical developments leading to a modern duty of care, followed by a more detailed discussion of current developments in the chain of care from state to citizen.

\section{The Chain of Care from State to Citizen}

Polities' interest in compatriots abroad has been related to commerce, control and community, in that historical order. From around $500 \mathrm{BCE}$ to the end of the Greek city-states, ${ }^{9}$ and again from the eleventh to the seventeenth century CE,

7 For instance, the United States: 'The us Department of State and our embassies and consulates abroad have no greater responsibility than the protection of us citizens overseas'; us Department of State, Foreign Affairs Manual: Volume 7, Consular Affair. (2013), available online at http://www.state.gov/documents/organization/86556.pdf.

8 Recent examples include the evacuation of Chinese citizens from Libya in 2011 and of Indian citizens from Yemen in 2015. See Shaio H. Zerba, 'China's Libya Evacuation Operation: A New Diplomatic Imperative — Overseas Citizen Protection', Journal of Contemporary China, vol. 23, no. 90 (2014), pp. 1093-1112; and Vijay Sakhuja, 'India's Yemeni Evacuation', Indian Defence Review, vol. 30, no. 2 (2015), available online at http://www.indiandefencereview .com/news/indias-yemeni-evacuation/ (190417).

9 Frank Adcock and D.J. Mosley, Diplomacy in Ancient Greece (London: Thames and Hudson, 1975), p. 11. 
the focus was on commerce, with the goal being to facilitate trade. However, early modern states also had a desire for control, and from the seventeenth to the nineteenth centuries the goal of keeping taxpayers and potential soldiers (the subjects) healthy and within the reach of the state was added to the desire to support commerce. ${ }^{10}$ With the coming of liberalism, nationalism, emerging political liberties and a somewhat free press, the relationship between state and inhabitants of the territory of the state changed. As contract theory and notions of citizenship replaced the idea of subjects, taking an interest in one's own citizens abroad came to be seen not only as a moral duty, but also as a political responsibility, particularly in states with a strong connection between 'the people' and the state. ${ }^{11}$ With the emergence of the embryonic welfare states in the second half of the nineteenth century, we also see the first articulation of what we can refer to as a 'duty of care' held by the state towards its citizens abroad, and with the later fleshing out of welfare states and the advent of mass tourism, the expectations for care abroad rose. Attempts at balancing the duty of care held by states by making travellers responsible (or 'responsibilizing' them) through travels warnings and voluntary travel registration have thus far been at best partially successful. ${ }^{12}$ When and where compatriots need care has thus undergone tremendous change over time, as have the reasons for seeking care.

States have handled these responsibilities directly or indirectly, through diplomatic personnel or intermediaries. Care directly through diplomatic personnel is currently on the wane. Even if contemporary foreign services spend considerable time, energy and money on 'consular affairs', the accredited diplomats (or consuls) typically handle only the most difficult or politicized instances of care..$^{13}$ Traditionally, the solution to the limited capacity of the

10 Halvard Leira and Iver B. Neumann, 'The Many Past Lives of the Consul', in J. Melissen and A.M. Fernandez (eds.), Consular Affairs and Diplomacy (Leiden: Martinus Nijhoff, 2011), pp. 225-246. See also Benjamin de Carvalho, 'The Making of the Political Subject: Subjects and Territory in the Formation of the State', Theory and Society, vol. 45 (2016), pp. 57-88.

11 Halvard Leira, “'Our Entire People are Natural Born Friends of Peace”: The Norwegian Foreign Policy of Peace', Swiss Political Science Review, vol. 19, no. 3 (2013), pp. 338-356.

12 Oded Löwenheim, 'The Responsibility to Responsibilize: Foreign Offices and the Issuing of Travel Warnings', International Political Sociology, vol. 1, no. 3 (2007), pp. 203-221; and Iver B. Neumann and Ole Jacob Sending, Governing the Global Polity: Practice, Mentality, Rationality (Ann Arbor, MI: University of Michigan Press, 2010).

13 Halvard Leira, 'Beskyttelsesplikt over alle grenser?', Norsk Statsvitenskapelig Tidsskrift, vol. 33, no. 1 (2017), pp. 78-97. Legally speaking, there is a difference between diplomatic protection and consular assistance, but since both involve providing care for compatriots, this distinction need not bother us here. See Annemarieke Künzli, 'Exercising 
diplomatic personnel has been to work through intermediaries. Many consular services have, for instance, relied heavily on members of the receiving state as their representatives. Today, carers are thus typically locally appointed honorary consuls. If care is relatively easy to give, these local consuls handle the matter.

Such contemporary consuls, who are typically citizens of the receiving state, spend considerable time helping citizens who are charged with crimes or have been sentenced, aiding with lost documents, and with hospitalization and repatriation. Even if these representatives have some rights of immunity according to the Vienna Convention of 1963, they typically have not been covered by any sending state's duty of care. These consuls form a link in the chain of care for citizens, but care is usually not offered to them. Consuls have from time to time had protection from flying the flag or showing the shield of the sending country, but this is as far as it goes. The reliance on receiving state personnel is not restricted to honorary consuls; even within embassies and consulates manned by career-diplomats, many tasks associated with care for compatriots are handled by locally hired staff. In such instances, local staff become another link in the chain of care. As discussed below, they potentially also become eligible for care themselves.

However important they might seem from a symbolic perspective, honorary consular posts to some extent hark back to the days of massive merchant marines, rather than look forward to the digital diplomacy of the third millennium. ${ }^{14}$ Growing needs for flexible care are likely to lead states to rely on more or less formalized agreements with private providers of care, who might already have expertise on the ground, and who are not regulated by diplomatic protocol. We see some of this in the establishment of public-private cooperation in crisis management and rescue operations, with the state becoming involved when private interests (and lives) are threatened abroad, and with established partnerships regarding the chartering of planes, etc., in times of crisis. ${ }^{15}$

Over the last decade, the need for care has grown and become less predictable, with repercussions for many foreign services in the form of operation centres, rapid-response teams and public-private partnerships, as well

Diplomatic Protection: The Fine Line between Litigation, Demarches and Consular Assistance', Zeitschrift für ausländisches öffentliches Recht und Völkerrecht, vol. 66, no. 2 (2006), pp. 321-350.

14 Melissen and Caesar-Gordon, "'Digital Diplomacy" and the Securing of Nationals in a Citizen-Centric World'.

15 Okano-Heijmans and Caesar-Gordon, 'Protecting the Worker-Citizen Abroad'. 
as increased use of digital diplomacy, in particular social media, in crisis situations. ${ }^{16}$ For the foreseeable future, carers in the field will nevertheless be necessary, and diplomatic personnel will be in need of care.

\section{Caring for the Carers}

For the last two centuries, diplomatic personnel have typically been able to aid compatriots in need without fear for their own safety. Earlier, the status of carers was, more often than not, precarious; now diplomats again seem to be living under increasing risk. While diplomatic personnel provide care for compatriots, they are thus also in need of care themselves, as suggested by the very image of the chain of care presented in the introduction. This need for care sometimes arises from diplomats providing care for compatriots, but in principle diplomats can be in need of care for any number of reasons. Following a brief historical background on the threats against carers, this section focuses on the current need for care for diplomats, physical as well as psychological.

\section{Threats against Carers}

Threats from Receiving States

Carers in a foreign country might be exposed to the same kind of threats as other foreigners, such as going bankrupt or being charged with violation of local laws. Natural disasters and accidents likewise do not distinguish between carers and others. However, with regard to man-made threats, being another state's agent always entails the additional risk of being targeted because of something that the principal has done, or something that the principal might symbolize. This might be the sending state, or diplomacy as an institution. In times and places where consuls or their equivalents have also been regarded as the first among equals among their compatriots, they have run the additional risk of being held responsible for acts done by their countrymen. Diplomats, consuls, and their residences and offices have thus been at risk for centuries. These risks have typically not been directly related to the care offered by these officers, but have nevertheless entailed that the carers themselves have been in need of care. Before the development of diplomatic protocol and international law concerning diplomatic immunities, these risks could well stem from host governments. And, as one would expect in any hierarchical system, the risks have been greater for officers with lower rank. Some examples will

16 Melissen and Caesar-Gordon, "'Digital Diplomacy" and the Securing of Nationals in a Citizen-Centric World', pp. 6-7. 
illustrate the severity of the challenge. In 1596, a French consul was executed in Alexandria, while dressed in his consular uniform. ${ }^{17}$ Another French consul was almost kicked to death in a meeting of the divan in Algiers, and several consuls in Salé around the mid-seventeenth century suffered imprisonment and had their houses looted..$^{18}$ Likewise, during the reign of Charles II (16601685), the English consul to Alger was killed, the consul to the Canary Islands was driven from the islands, and consuls to Madeira and Cadiz were jailed. ${ }^{19}$ During the French bombardment of Algiers in 1683, the French consul was tied to the mouth of a cannon and blasted off. As interaction became denser and more regulated, the risks subsided somewhat. When in 1808, the Danish consul to Algiers had to inform the Dey that he would not receive any gifts from Denmark that year, he was promptly laid in chains and sentenced to slave labour. Already the following day, the other European consuls made a joint demarche to the Dey and had the consul released. ${ }^{20}$ Such action is perfectly parallel to what could be found in other diplomatic corps, ${ }^{21}$ but for diplomats the risks were reduced some centuries earlier.

At the congress of Vienna in 1815 , the basics of diplomatic immunity were agreed upon, and even though consuls were not fully part of the codification until the treaty on consular affairs from 1963 , threats from hosting states against carers largely subsided. ${ }^{22}$ Hosting states in principle now have a separate duty of protection for foreign diplomats. ${ }^{23}$ Again, no rule is without exception: during times of upheaval, states that might even question the notion of diplomacy have tacitly or openly supported attacks on foreign representatives, such as during the cultural revolution in China in 1967, the Islamic revolution in Iran in 1979 and during the 'Mohammed Cartoon Crisis' of 2006. Receiving countries have also been accused of not doing enough to protect carers, as when Turkey blamed Iraq for not protecting its consulate in Mosul well enough in

17 Niels Stensgaard, 'Consuls and Nations in the Levant from 1570-1650', Scandinavian Economic History Review, vol. 17 (1967), p. 18.

18 Peter Lamborn Wilson, Pirate Utopias: Moorish Corsairs and European Renegades (New York, NY: Autonomedia, 2nd edition 2003), pp. 35 and 162-163.

19 Violet Barbour, 'Consular Service in the Reign of Charles II', American Historical Review, vol. 33 (1928), p. 571.

$20 \quad$ Knud J.V. Jespersen and Ole Feldbæk, Revanche og neutralitet 1648-1814: Dansk udenrigspolitisk historie, bd. 2. (Copenhagen: Danmarks Nationalleksikon, 2002), p. 488.

21 M.S. Anderson, The Rise of Modern Diplomacy, 1450-1919 (London: Longman, 1993), p. 54.

22 Additional protection, as well as procedures for punishment in case of crimes, was laid down in the UN Convention on the Prevention and Punishment of Crimes against Internationally Protected Persons, including Diplomatic Agents, from 1973.

23 See the discussion in Barker, The Protection of Diplomatic Personnel, pp. 45-61. 
the summer of 2014, allowing the (self-proclaimed) Islamic State to take the consul general and 48 other Turks as hostages. ${ }^{24}$

\section{Threats from Non-state Actors}

While threats from states have subsided, non-state actors have continued to pose a risk to diplomats and consuls, a risk that it could be argued is growing. Some such risks for carers are simply the result of being in the wrong place at the wrong time, as in the case of mob dynamics such as the one referenced in this article's introduction. Mob reactions against foreigners have indeed not been unusual, and the carers have from time to time been caught up in them. More common are targeted attacks against carers and their offices or residences. In countries with civil war or domestic unrest, attacks against foreign embassies and/or personnel can be political statements against foreign influence in general, or specifically against one distinct country (such as the repeated attacks against the us Embassy in Saigon during the Vietnam War). The attacks on Western embassies during the 'Mohammed Cartoon Crisis' are a fairly recent example of such dynamics. Such attacks are nevertheless predictable to some extent; it should, for instance, not be surprising when parties to civil wars in the Middle East attack the embassies or consulates of the United States or other Western states. More challenging is the globalization of such risks, where political groups with an agenda in (or directed against) one specific state are willing to attack representatives of the state anywhere in the world. The attack by the Red Army Faction (RAF) against the West German Embassy in Stockholm in 1975 is one example of domestic terrorism being exported, while the many attacks against Israeli embassies, and attacks against us embassies and consulates by different Islamist groups, are examples of more diffuse global terrorism.

While media coverage can seem to indicate an increase in attacks against diplomats and diplomatic sites, overall numbers from the Global Terrorism Database suggest that attacks against traditional diplomacy (defined as embassies and consulates) peaked both in overall number and in overall casualties around 1980 (almost 100 attacks per year) and again around 1990 (between 80 and 90 attacks per year), with an increase over the last decade (from around

24 'Turkish PM Accuses Iraq of Not Protecting its Mosul Consulate', Hurryiet Daily (17 June 2014), available online at http://www.hurriyetdailynews.com/turkish-pm-accuses-iraq -of-not-protecting-its-mosul-consulate-.aspx?pageID $=238 \& \mathrm{nID}=67908 \&$ NewsCatID $=510$ (280115). 
30 attacks per year to around 50 attacks per year). ${ }^{25}$ However, if we look at attacks against diplomacy somewhat more broadly defined, using the category 'Government (Diplomatic)', which also includes international organizations and peacekeepers, etc., the number of incidents per year has quadrupled since 2000 (from less than 40 in 1998 to 160 in 2014) and is now higher than around 1980 (around 120 per year), if not yet as high as around 1990 (almost 200 per year). ${ }^{26}$ While approximately three-quarters of attacks include no fatalities, an increase in numbers is nevertheless likely to lead to increased insecurity and stricter regulations. Although embassies provide bigger, more visible targets, thus increasing the symbolic effect of an attack, attacks are also directed against consulates, which are presumably easier targets. The attack against the us Consulate in Benghazi, Libya, in 2012 was a prime example of this.

\section{Protecting Carers}

As part of the relationship between principal and agent, sending states typically try to protect their diplomatic personnel, either directly or indirectly. This section deals with direct protection; and the next section with indirect protection. Direct protection can take place through evacuation, through establishment of physical structures and training, and through taking care of the mental well-being of diplomats. Indirect protection takes place through the use of local staff and outsourcing (in particular of protection). When diplomatic personnel are threatened, the chain of care is typically short, with the sending state taking direct responsibility for its agents as both employees and citizens. When the agents are of a different nationality, the equation becomes more complicated.

\section{Evacuation}

To some extent, the risks faced by the carers are a function of their role. While travellers can be advised to stay away from certain areas, and evacuated when crisis hits, diplomatic personnel typically stay until the situation becomes untenable. If crisis situations develop over time, diplomatic personnel are often also evacuated. Most often this happens with the consent, or at least the

25 National Consortium for the Study of Terrorism and Responses to Terrorism, Global Terrorism Database, staRt (2013), available online at http://www.start.umd.edu/gtd (o80616); compare with Barker, The Protection of Diplomatic Personnel, p. 14. The numbers unfortunately do not allow us to compare 'attacks per unit'.

26 Some of the increase, but far from all of it, has been associated with the Us foreign service; see Eugenio Cusumano, 'Diplomatic Security for Hire: The Causes and Implications of Outsourcing Embassy Protection', The Hague Journal of Diplomacy, vol. 12 (2016), pp. 1-29. 
tacit acceptance, of host states, even in the case of war between the states in question. However, as in the case of the Iran hostage crisis from November 1979-January 1981, host states can hinder such evacuation and use diplomats as bargaining chips. As we see below, in cases of evacuation, deciding who to evacuate might not be clear-cut.

\section{Physical Structures and Training}

Evacuations are typically related to escalating crises, and the disruption or draw-down of representation. Yet most crises hit suddenly, with carers and their offices typically attacked by surprise. Permanent physical structures are thus seen as essential to protection and care, and the trend has been towards increasing protection. The most well-known example of enhanced security through physical structures can be found in the us foreign service, where, after the Us Embassy in Tehran takeover in 1979, the Lebanon bombing in 1983, and again after the East African Us embassy attacks in 1998, security was strengthened, and embassies and consulates were typically moved away from city centres and became heavily fortified. ${ }^{27}$ While there has been a reaction against 'bunker embassies', ${ }^{28}$ the reaction has typically been centred on relations with the host country. ${ }^{29}$ It is argued, probably rightfully, that diplomats stuck in these bunkers will not be able to learn about the countries in which they live, and thus will become less-effective diplomats. ${ }^{30}$ However, as many diplomatic services strenuously try to avoid their personnel 'going native' in the first place,

27 The following discussion is based primarily on the American example, but the points should be of more general validity, even if smaller states might have less need, desire, or capacity to fortify their external presence.

28 Kenneth H. Torp, 'Don't Turn US Embassies into Bunkers', The Seattle Times (8 February 2013), available online at http://seattletimes.com/html/opinion/2020320055_kennethtor popedxml.html (290115).

29 Joshua E. Keating, 'Bunker Mentality', Foreign Policy (2012), available online at http:// foreignpolicy.com/2012/og/14/bunker-mentality/ (101116); and John Kerry and William Cohen, 'Concrete Bunker us Embassies Send Wrong Message', CNN.com (2010), available online at http://edition.cnn.com/2010/OPINION/05/11/kerry.cohen.embassies/ (101116).

30 The parallel to military forces is striking: enhanced force protection has been seen as part of a process that would remove the advantage that lightly equipped conscripted soldiers were believed to have over heavy armoured professionals in connecting with the locals and fostering peace in the mission area. See Nina Græger, 'Home and Away"? Internationalism and Territory in the Post-1990 Norwegian Defence Discourse', Cooperation and Conflict, vol. 44, no. 1 (2011), pp. 1-18. 
the move to bunker embassies might express existing identity constructs, and perhaps strengthen them, rather than creating entirely new ones. ${ }^{31}$

It also seems likely that a retreat into 'bunker' embassies will have further ramifications. While there has been some academic study of diplomatic architecture, ${ }^{32}$ this has typically been oriented towards the expressive features of architecture, with embassies as a form of public diplomacy. In the case of fortified embassies, the image projected is likely to be one of threat and power, which is not the best starting point for diplomatic practice. ${ }^{33}$ In the light of the overall topic of this article, it is also important that by isolating themselves, diplomats and consuls become less able carers. A consul who is inaccessible behind barbed wire, and can only move around with armed guards, will not be as effective a carer as one who is free to roam.

These suggested effects of fortifying and securitizing are of obvious interest, but they have not been given much attention so far in diplomatic studies beyond empirical description. Furthermore, there has been little sustained interest in the interplay of architecture and diplomacy, how different materializations of diplomatic sites affect diplomatic activity in different ways, beyond the straightforward relations with the host society. To get a better grip on these issues, recent insights from the study of humanitarianism can be useful. While humanitarians and diplomats have often constructed themselves partly in opposition to one another, increases in risk and similarities in the response to risk have created greater likeness between the two communities, for instance with 'forms of aid worker subjectivity being called forth that accept segregated living as necessary, even desirable. ${ }^{34}$ For diplomats, some sort of segregation has traditionally been seen as desirable, so on this count, we should expect

31 I owe this point to one of this article's perceptive peer reviewers.

32 Jane C. Loeffler, The Architecture of Diplomacy: Building America's Embassies (Hudson, NY: Princeton Architectural Press, 1998); and Theodore Ron Robin, Enclaves of America: The Rhetoric of American Political Architecture Abroad, 1900-1965 (Princeton, NJ: Princeton University Press, 1992).

33 It also bears mentioning that in a meta-review of counter-terrorism policy (admittedly based on data up until only 2002), the authors found that 'In terms of interventions which physically fortified embassies as well as increased security and protection for diplomats, many findings were non-significant and close to o, indicating that there is little scientific evidence of interventions being effective in reducing terrorism against these targets'; see Cynthia Lum, Leslie W. Kennedy and Alison Sherley, 'Is Counter-Terrorism Policy Evidence-Based? What Works, What Harms, and What is Unknown?', Psicothema, vol. 20, no. 1 (2008), p. 40.

34 Mark Duffield, 'Risk Management and the Bunkering of the Aid Industry', Development Dialogue (April 2012), p. 22. 
the experiences to have important similarities. It should be stressed that what we are seeing here is an example of humanitarians becoming more like diplomats. Diplomacy, understood as 'the mediation of estrangement', ${ }^{35}$ has always relied on separation between the host society and diplomats (thus also the description of diplomatic culture as a 'third culture'), while humanitarians have sought much closer connection with beneficiaries. It could thus be argued that diplomatic studies have taken separation between diplomats and their host society for granted, without contemplating either the effects of this separation or the possible changes in how the separation is established. While diplomacy relies on at least some estrangement between diplomats and their host society, we should expect it to matter if this estrangement is expressed through social mores or through barbed wire. On the other hand, studies of humanitarianism have had to reflect on what, for humanitarians, are entirely new practices of separation. These studies should be of interest for diplomatic studies as well.

Over the last decade, a number of authors have discussed how increased risk and increased fear of risk - for example, in relation to insurance concerns has led to 'spatialization' and materialization of the aid industry in general, ${ }^{36}$ including but not limited to international non-governmental organizations (INGOS), non-governmental organizations (NGOS), humanitarian responders and peacekeepers. The most visible expression of this has been the humanitarian compound, ${ }^{37}$ which has been seen to lead to a 'bunkering' of the aid industry, ${ }^{38}$ much like what has been decried for diplomacy. In the same way as for diplomacy, but more acutely, since care is the main function of the aid industry and only part of the portfolio of diplomacy, the need for security comes into conflict with 'the need to have an open and easy dialog with one's beneficiaries.' ${ }^{39}$ The same challenge arises for peacekeepers, who typically have fortified headquarters 'replete with blast walls, razor wire, closed circuit television, intercom systems, entry-processing offices and static and mobile patrols, [which] speaks to a reified security presence organized by, and on behalf of, international staff - many of whom will rarely, if ever, come into

35 James Der Derian, On Diplomacy: A Genealogy of Western Estrangement (Oxford: Blackwell, 1987), p. 42.

36 Lisa Smirl, 'Building the Other, Constructing Ourselves: Spatial Dimensions of International Humanitarian Response', International Political Sociology, vol. 2, no. 2 (2008), pp. 236-253.

37 Mark Duffield, 'Risk Management and the Fortified Aid Compound: Everyday Life in Post-Interventionary Society',Journal of Intervention and Statebuilding, vol. 4, no. 4 (2010), pp. 453-474.

38 Duffield 'Risk Management and the Fortified Aid Compound'.

39 Smirl, 'Building the Other, Constructing Ourselves', p. 241. 
direct contact with their hosts - the beneficiary population' ${ }^{40}$ Separation from the host society is, however, only the most obvious effect of compound life. As Mark Duffield stresses, when coupled with field security training (and one could add, regularized practice), compounds 'become embedded in wider technologies of security in which buildings "offer cues suggesting how people should act. They tell us our relationships with one another"'41

Living inside a fortified compound, leaving only in armoured vehicles or accompanied by bodyguards, going through compulsory security training, and repeating security procedures so often that they become regularized everyday practice, is bound to have effects on both identity and agency. At a very basic level, separation helps construct Selves and Others, as diplomats have always realized. However, this form of separation, with defensive postures and rigid security, constructs a very specific outside, populated with Others who are not only different, but dangerous. Put simply, living in a bunker makes for a conception of outsiders as at least potential enemies. Furthermore, the standardization of both building requirements and training regimens makes for generalized, rather than specific, dangers. As Duffield notes, 'in most cases, defensive aid architecture spreads; not as a response to clear and present danger, but as an insurance-driven exercise in minimizing risk: ${ }^{42}$ The state that exercises its duty of care towards its diplomats is not substantially different from the INGO that exercises its duty of care towards its employees.

Creating defensive-minded agents, who are accustomed to seeing the outside as dangerous and thus regulating their activity accordingly, has a number of likely effects. One of them is self-perpetuation. Most organizations have forms of 'hardship differentials' that are paid to staff in particularly dangerous places. A constant construction of danger through buildings, training and practice is likely to influence both diplomatic personnel and other agents to argue in favour of continued or increased hardship differentials, thus creating a self-reinforcing dynamic. Likewise, persistent perceptions of danger are likely to influence reporting back to national capitals. And since such reporting feeds into travel advice, this perceived danger will in most cases lead to restrictive travel advice, with potential political costs. ${ }^{43}$

The sum total of projects to secure the carers - fortified buildings, security training and armoured vehicles, etc. - means that at a number of

Paul Higate and Marsha Henry, 'Space, Performance and Everyday Security in the Peacekeeping Context', International Peacekeeping, vol. 17, no. 1 (2010), p. 36.

41 Duffield, 'Risk Management and the Fortified Aid Compound', p. 455, citing Montgomery.

42 Duffield, 'Risk Management and the Fortified Aid Compound', p. 468.

43 Löwenheim, 'The Responsibility to Responsibilize'. 
diplomatic posts, taking care of the carers takes up an inordinate amount of time and money. By way of example, in a recent survey, just short of half of the Norwegian foreign service's posts reported that they used 'very much' or 'much' time on matters relating to the security of the post and its employees. ${ }^{44}$ At some posts, it seems valid to raise the question of whether the carers have the capacity actually to provide care, or whether they are reduced merely to caring for themselves.

\section{Psychological Care}

While the need for physical protection in the field has been widely acknowledged, if not discussed in depth in the academic literature, the possible need for psychological care for diplomats before, during and after posting to hardship positions has hardly been discussed at all. This is all the more surprising, given the fairly high attention paid to post-traumatic stress disorder (PTSD) and other mental challenges facing military personnel stationed in dangerous places. Even more surprising is the lack of systematic thinking about such issues in diplomatic circles. In a survey that mapped policies (and the lack thereof) in international governmental organizations, the authors found 'little consensus about the best approach to determining tour lengths for high-threat diplomatic postings, and most of the organizations surveyed adopted a range of measures, frequently not as part of a formal policy, to address the psychosocial risks of such deployments. ${ }^{45}$

Data about postings to hardship positions are limited, but some findings are worth singling out. In overall assessments, drawing also on other professions, it has been found that decreasing mental health is more prevalent among personnel on their first posting and if the posting's length is changed during the tour, and also associated with longer deployments. ${ }^{46}$ In a study of British Foreign \& Commonwealth Office (FCO) diplomats, the authors found that, contrary to what might have been expected, the diplomats who had been posted to Iraq or Afghanistan were less driven by career advancement and more driven by adventure than their counterparts in non-hardship postings.

44 Halvard Leira and Ulf Sverdrup, Norske interesser og norske utestasjoner [Norwegian Interests and Norwegian Foreign Posts], NUPI report no. 4/2015 (Oslo: NUPI, 2015), p. 27.

45 R. Dunn, V. Kemp, D. Patel, R. Williams and N. Greenberg, 'Deployment Guidelines for Diplomats: Current Policy and Practice', Occupational Medicine, vol. 65 (2015), p. 540.

46 R. Dunn, R. Williams, V. Kemp, D. Patel and N. Greenberg, 'Systematic Review: Deployment Length and the Mental Health of Diplomats', Occupational Medicine, vol. 65 (2015), p. 37. 
Furthermore, they also found their postings more rewarding. ${ }^{47}$ It might thus be the case in the FCO that self-selection leads the most suitable diplomats to hardship postings. ${ }^{48}$ This might help to explain the key finding from the same study, that even though there was a somewhat higher prevalence of PTSD symptoms among the diplomats who had been exposed to trauma, 'deployment to conflict zones does not necessarily lead to deterioration in mental health.49 In a parallel finding, in the Canadian foreign service, the diplomats posted to hardship positions reported higher levels of satisfaction than those assigned to countries of lesser hardship. ${ }^{50}$ These findings are somewhat at odds with findings from the United States, however, where as many as 40 per cent of those diplomats who had served in danger zones had some PTSD symptoms. ${ }^{51}$ It should be noted that unlike in the British FCO, serving in hardship posts is now a requirement for career advancement for us State Department diplomats, thus removing both the possible benefits of self-selection and the agency of the individual diplomats. This is particularly problematic, since lack of active choice and predictability is found to be increasing the risk of mental illness when serving in hardship posts. ${ }^{52}$

\section{Delegation of Duty and the Limits of Care}

Diplomatic and consular interaction has always implied some delegation of duties, with embassies relying on locally hired intermediaries for both practical and diplomatic tasks, and with residents of the receiving polity acting as honorary consuls. This has had a practical dimension, but has also served as indirect protection of the diplomatic personnel of the sending state, by keeping them out of harm's way and by adding external security. Yet delegation of duty and outsourcing has also raised questions about the limits of care - to what extent do the state principals owe a duty of care to these secondary agents?

47 Jessamy M. Hibberd and Neil Greenberg, 'Coping with the Impact of Working in a Conflict Zone: A Comparative Study of Diplomatic Staff', Journal of Occupational and Environmental Medicine, vol. 53, no. 4 (2011), p. 354.

48 Hibberd and Greenberg, 'Coping with the Impact of Working in a Conflict Zone', p. 355.

49 Hibberd and Greenberg, 'Coping with the Impact of Working in a Conflict Zone', p. 355.

50 Daniel J. Kealey, Doug MacDonald and Thomas Vulpe, 'Intercultural Competence and its Relevance for International Diplomacy', in Hannah Slavik (ed.), Intercultural Communication and Diplomacy (Valetta, Malta: DiploFoundation, 2004), p. 435.

$5^{1} \quad$ Hibberd and Greenberg, 'Coping with the Impact of Working in a Conflict Zone', p. $35^{2}$.

$5^{2}$ Dunn et al., 'Systematic Review', p. 34. 


\section{Locally Hired Staff under Duress}

In crisis situations, the duty of care towards career diplomatic personnel is self-evident, but the relationship between sending states and local staff is not. Here the chain of care might be broken. The situation around the fall of Saigon in 1975 provides an illuminating example. Although many Vietnamese who had been associated with the American presence in South Vietnam were left behind to uncertain destinies, the United States did evacuate thousands of Vietnamese personnel and their families, including embassy staff. Other countries chose differently. The Canadian Embassy in Saigon evacuated with souvenirs and cars, but without the local staff, ${ }^{53}$ and in the Australian case, the Australian government, wanting to restrict immigration, overruled the ambassador and granted asylum to only one member of the local staff. ${ }^{54}$ In the Canadian case, the Saigon experience was perceived as shameful, so when the Canadian Embassy in Beirut evacuated/relocated to Damascus in 1985, the local members of staff were given three options: 'to retain their positions at the new location in Damascus, to retire with severance and pension, or to immigrate to Canada. 55 The question of how to deal with local staff is recurring, with Baghdad and Kabul being the two most obvious examples over the last decade. While the United States has put in place special visa programmes for local staff in potential danger, ${ }^{56}$ other countries have been reluctant to grant asylum to local staff. ${ }^{57}$ The duty of care is still associated primarily with nationality, and not with function. ${ }^{58}$

53 Veronica Strong-Boag and Rupa Bagga, 'Saving, Kidnapping or Something of Both? Canada and the Vietnam/Cambodia Babylift, Spring 1975', American Review of Canadian Studies, vol. 39, no. 3 (2009), p. 274.

54 Nathalie Huynh Chau Nguyen, 'Memory in the Aftermath of War: Australian Responses to the Vietnamese Refugee Crisis of 1975', Canadian Journal of Law and Society, vol. 30, no. 2 (2015), pp. 189-192.

55 Michael Bell and Michael J. Molloy, 'Crisis Decision-Making in Canadian Foreign Policy: Diplomatic Representation in the Levant, 1984-1986', International Journal, vol. 68, no. 2 (2013), p. 391.

56 Andorra Bruno, Iraqi and Afghan Special Immigrant Visa Programs (Washington, DC: Congressional Research Service, 2015).

57 In the Norwegian case, fired local staff have claimed that they have been 'left behind to die', VG (4 July 2016), available online at http://www.vg.no/nyheter/utenriks/afghanistan/19 -fikk-sparken-fra-norsk-ambassade-ud-etterlater-oss-for-aa-doe/a/23730320/ (10116).

$5^{8}$ It is an illuminating parallel, that when us embassy personnel were evacuated from Kinshasa in 1991, a separate evacuation of the pets of personnel was arranged soon after. See 'Who Let the Dogs Out? A Pet Evacuation from Kinshasa', available online at http:// adst.org/2016/o6/let-dogs-pet-evacuation-kinshasa/ (0201717); see also, more generally, 


\section{Security Contractors}

In addition to infrastructure, training and locally hired staff, protection by private military and security company (PMSC) contractors has increased vastly. It should be stressed immediately that protection provided by specialized military/police forces dispatched from the sending state has been restricted to great and middle powers. Most other states have had to rely on some sort of outsourcing of protection, if such protection has been needed. What has changed over recent decades, in parallel with the wars in Afghanistan and Iraq and the growth in terrorism, is how even great and middle powers now outsource the protection of their diplomats, to the extent that 'Contractors now account for roughly $90 \%$ of the [US] Diplomatic Security Bureau's workforce'. ${ }^{59}$ Some of these contractors are locally hired guards, while others are operatives of multinational private military and security companies. The reasons behind this growth are numerous, including perceived cost-efficiency, desire to restrict military forces to front-line duty, ideological preferences and bureaucratic politics. ${ }^{60}$ The results have nevertheless been mixed, with questionable cost-savings, sometimes reduced security for the diplomats, and abuses of power, leading to questioning of whether outsourcing leads to 'accountability gaps' ${ }^{61}$ In the current perspective, it also makes sense to ask whether outsourcing might lead to gaps in duty of care. In the not infrequent instances when the contractors are from the sending state, often former police or military personnel, what sort of duty does the state hold towards them? An interesting example concerns the Swedish foreign service, where privately hired 'security coordinators' in the Swedish embassies in Iraq, Afghanistan and Pakistan were given diplomatic status. ${ }^{62}$ In this case, the duty of care quite clearly extends also to the contractors. This has, on the other hand, not been the case for the many locally hired guards, or for the majority of contractors from PMSCs.

Halvard Leira and Iver B. Neumann, 'Beastly Diplomacy', The Hague Journal of Diplomacy, vol. 12, no. 4 (2016), DOI: 10.1163/1871191X-12341355.

59 Cusumano, 'Diplomatic Security for Hire', p. 13.

6o Eugenio Cusumano and Christopher Kinsey, 'Bureaucratic Interests and the Outsourcing of Security: The Privatization of Diplomatic Protection in the United States and the United Kingdom', Armed Forces and Society, vol. 41, no. 4 (2015), pp. 591-615.

61 Cusumano, 'Diplomatic Security for Hire', pp. 3-4.

62 Joakim Berndtsson and Maria Stern, 'Private Security Guards: Authority, Control and Governance?', in Rita Abrahamsen and Anna Leander (eds.), Routledge Handbook of Private Security Studies (Milton Park: Routledge, 2016), p. 56. 


\section{Conclusion}

The notion of diplomats as carers is often overlooked in favour of other diplomatic functions, such as representation and communication. In a world where ever-increasing numbers of compatriots are in need of care, and where caring is seen as a duty, the likelihood of the duty of care becoming ever more relevant nevertheless seems high. At the same time, the carers — that is, the diplomatic personnel - are in more need of care themselves. States are scrambling to find solutions to both these sets of political and normative challenges, but these solutions tend to create unforeseen consequences, and yet new challenges.

As discussed above, states are caught between their desire for citizens to govern themselves, the citizens' increasing demand for care and the need to care for the carers. States typically try to handle this through modifications to the original chain of care: adding more links through honorary consuls or private actors; excluding links through providing care from crisis centres and emergency teams dispatched from the sending states; or reducing the chain to a single link by making the citizens responsible and the use of digital diplomacy. None of these solutions are perfect. Adding new links raises questions about whether the state has a duty of care for honorary consuls or private contractors, while making citizens responsible for themselves and digital means are unlikely to be enough in crisis. Crisis centres and emergency teams have the benefit of signalling state care, but might prove costly and ineffectual. A mix between the different approaches would seem to be the most likely course for states.

The chain of care between the state and diplomatic personnel is shorter, and in one sense less complicated. There is no doubt that states must care for their personnel. Even so, as illustrated by the question of evacuations and private security contractors, how far the duty of care reaches is not obvious. Furthermore, the very steps taken to protect diplomatic personnel seem likely to make them less capable of being effective and efficient diplomats, as well as carers.

The tensions that have been described here can to some extent be described as tensions between space and pace, between diplomacy understood in terms of embassies and residences, and diplomacy understood as a bundle of practices, with care being one such practice. Moreover, as discussed above, the development of the duty of care pulls in both directions. Whereas the duty of care towards citizens privileges diplomacy as practice, with a combination of rapid response and local presence, particularly in places of relatively high risk and with relatively many citizens, the duty of care towards diplomats suggests that diplomats should be concentrated and secure, and should avoid areas of 
risk. To the extent that states are ever more reluctant to expose their diplomats to danger, one probable outcome would seem to be a growing reliance on private intermediaries to carry out care 'on the ground'. Reliance on local staff and contractors nevertheless does not solve the challenges of care; they simply make the chains of care longer. However, the political imperative of caring for citizens and diplomats might trump the more diffuse moral responsibility to care for personnel at the end of the chain of care.

For the broader study of diplomacy, this exploratory analysis generally suggests that the recent increase in studies of consular work needs to be continued. It also seems obvious that there is more room for discussing the intersection of political and normative drivers in diplomacy. More specifically, I would suggest that the recent ethnographic studies of 'high' diplomacy in capitals should be supplemented with studies of actual consular work. At an aggregate level, comparative studies of how the duty of care is operationalized would be extremely useful, as would studies of the effects on embassy security and the capacity for care. Finally, I would suggest that diplomatic studies face a moral imperative, in creating studies of the psychological effects of hardship postings, such as have been the order of the day in studies of military forces for a number of years. We, as societies, owe this to the diplomats providing care for our fellow citizens abroad.

Halvard Leira is Senior Research Fellow at the Norwegian Institute of International Affairs (NUPI). His research focuses on diplomacy, foreign policy, international thought and historical international relations. His work has appeared in, among others, Review of International Studies, Millennium, Leiden Journal of International Law, International Studies Perspectives, The Hague Journal of Diplomacy, Global Society, and Cooperation and Conflict. Leira was co-editor of the Sage Library of International Relations series International Diplomacy (2013) and Historical International Relations (2015). He is a founder member and former section chair of the Historical International Relations section of the International Studies Association and programme chair of the 2018 Pan European Conference on International Relations. 